\title{
The Severity of Vestibular Dysfunction in Deafness as a Determinant of Comorbid Hyperactivity or Anxiety
}

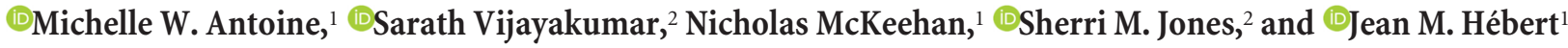 \\ ${ }^{1}$ Department of Neuroscience, Albert Einstein College of Medicine, Bronx, New York 10461, and ${ }^{2}$ Department of Special Education and Communication \\ Disorders, University of Nebraska-Lincoln, Lincoln, Nebraska 68583
}

Attention-deficit/hyperactivity disorder (ADHD) and anxiety-related disorders occur at rates 2-3 times higher in deaf compared with hearing children. Potential explanations for these elevated rates and the heterogeneity of behavioral disorders associated with deafness have usually focused on socio-environmental rather than biological effects. Children with the 22q11.2 deletion or duplication syndromes often display hearing loss and behavioral disorders, including ADHD and anxiety-related disorders. Here, we show that mouse mutants with either a gain or loss of function of the T-Box transcription factor gene, $T b x 1$, which lies within the $22 \mathrm{q} 11.2$ region and is responsible for most of the syndromic defects, exhibit inner ear defects and hyperactivity. Furthermore, we show that (1) inner ear dysfunction due to the tissue-specific loss of Tbx1 or Slc12a2, which encodes a sodium-potassium-chloride cotransporter and is also necessary for inner ear function, causes hyperactivity; (2) vestibular rather than auditory failure causes hyperactivity; and (3) the severity rather than the age of onset of vestibular dysfunction differentiates whether hyperactivity or anxiety co-occurs with inner ear dysfunction. Together, these findings highlight a biological link between inner ear dysfunction and behavioral disorders and how sensory abnormalities can contribute to the etiology of disorders traditionally considered of cerebral origin.

Key words: 22q11.2; hyperactivity; inner ear; Nkcc1; Slc12a2; Tbx1

\section{Significance Statement}

This study examines the biological rather than socio-environmental reasons why hyperactivity and anxiety disorders occur at higher rates in deaf individuals. Using conditional genetic approaches in mice, the authors show that (1) inner ear dysfunction due to either Tbx1 or Slc12a2 mutations cause hyperactivity; (2) it is vestibular dysfunction, which frequently co-occurs with deafness but often remains undiagnosed, rather than auditory dysfunction that causes hyperactivity and anxiety-related symptoms; and (3) the severity of vestibular dysfunction can predict whether hyperactivity or anxiety coexist with inner ear dysfunction. These findings suggest a need to evaluate vestibular function in hearing impaired individuals, especially those who exhibit hyperactive and anxiety-related symptoms.

\section{Introduction}

The inner ear consists of two sensory components: the cochlea, devoted to hearing; and the vestibular end organs, which aid in balance control. Given these established functions, it remains

\footnotetext{
Received Nov. 17, 2016; revised March 29, 2017; accepted April 2, 2017.

Author contributions: M.W.A. designed research; M.W.A., S.V., and N.M. performed research; M.W.A., S.V., N.M., S.M.J., and J.M.H. analyzed data; M.W.A. and J.M.H. wrote the paper.

This work was supported by National Institutes of Health Grants MH083804, NS088943, and HD090260 to J.M.H. M.W.A. was supported in part by a University of California Miller Research Fellowship.

The authors declare no competing financial interests.

Correspondence should be addressed to either of the following: Dr. Michelle W. Antoine, Department of Neuroscience, Albert Einstein College of Medicine, Bronx, NY 10461. E-mail: mwantoine@berkeley.edu; or Dr. Jean M. Hébert, Department of Special Education and Communication Disorders, University of Nebraska-Lincoln, Lincoln, NE 68583. E-mail: jean.hebert@einstein.yu.edu.

M.W. Antoine's present address: Miller Institute for Basic Research in Science, University of California, Berkeley, CA 94720.

DOI:10.1523/JNEUROSCI.3545-16.2017

Copyright $\odot 2017$ the authors $\quad 0270-6474 / 17 / 375144-11 \$ 15.00 / 0$
}

unresolved why externalizing symptoms such as hyperactivity and internalizing symptoms such as anxiety occur at $\sim 3$ times the rate among hearing impaired versus hearing children and adolescents (Hindley, 1994; Hindley et al., 1994; Hindley, 2000; van Eldik et al., 2004; van Gent et al., 2007). Several reports suggest that nonbiological factors, including poor-parent child communication as well as insufficient communication skills and selfcontrol, promote the behavioral and emotional problems (Furth, 1966; Lesser and Easser, 1972; Reivich and Rothrock, 1972; Vostanis et al., 1997; van Eldik et al., 2004; van Gent et al., 2007). However, mouse models of inner ear dysfunction also support a biological basis for the association between psychopathology and deficient ear function.

Analysis of mice with null or tissue-specific mutations in Slc12a2, which encodes $\mathrm{Na}^{+}-\mathrm{K}^{+}-2 \mathrm{Cl}^{-}$cotransporter necessary for inner ear function (Delpire et al., 1999; Flagella et al., 1999; Pace et al., 2000; Antoine et al., 2013), revealed that severe inner 
ear dysfunction can alter brain function to promote hyperactivity (Antoine et al., 2013). In the 22q11.2 deletion syndrome, children and adolescents display hearing loss and an unexplained increased risk of developing attention-deficit/hyperactivity disorder (ADHD) with a prevalence of $24 \%-37 \%$ versus $6.4 \%$ in controls (Schneider et al., 2014). The T-Box transcription factor gene, $T B X 1$, which lies within the 22q11.2 chromosomal region, is responsible for most of the physical defects associated with the syndrome (Yagi et al., 2003; Liao et al., 2004; Zweier et al., 2007; Ogata et al., 2014). Duplications of the 22q11.2 chromosomal region that include $T B X 1$ or gain-of-function missense mutations in $T B X 1$ can result in the same phenotypic spectrum as haploinsufficiency caused by deletions or loss-of-function mutations in humans and mice (Funke et al., 2001; Zweier et al., 2007; Weisfeld-Adams et al., 2012; Freyer et al., 2013; van Amelsvoort et al., 2016). The phenotypic spectra for both decreased and increased TBX1 function include inner ear malformations and dysfunction in mice (Funke et al., 2001; Vitelli et al., 2003; Liao et al., 2004; Arnold et al., 2006) and similarly in humans with 22q11.2 deletion syndrome (Digilio et al., 1999; Reyes et al., 1999; Swillen et al., 1999; Emanuel et al., 2001). The question remains: does inner ear dysfunction caused by gain or loss of Tbx1 function result in central changes that lead to behavioral manifestations?

Not all children with hearing loss are chronically hyperactive or anxious. A biological factor possibly accounting for some of the variability is vestibular dysfunction (VD), which occurs in $18 \%-82 \%$ of children with profound hearing loss (Arnvig, 1955; Cushing et al., 2008; O'Reilly et al., 2011). Moreover, the likelihood of VD occurring with hearing loss is increased in cases where hearing loss is profound, acquired through viral or bacterial infection or due to the inheritance of protein-truncating mutations (Arnvig, 1955; Dodson et al., 2011). Mouse models of inner ear dysfunction typically exhibit both auditory and vestibular failure, making it difficult to distinguish the contribution of each, if any, to promoting hyperactive behavior. Additionally, the use of ototoxic drugs or surgical methods, such as wide vestibulotomy or labyrinthectomy, to eliminate vestibular function frequently damages both inner ear systems concurrently (Smouha and Inouye, 1999). Here, using conditional genetic approaches in mice, we address the causal relationship between inner ear dysfunction (auditory and vestibular) and behavioral phenotypes. Our findings suggest that the severity of VD determines the behavioral manifestations that occur with deafness.

\section{Materials and Methods}

Mice. All experiments adhere to the guidelines and procedures of the Institutional Animal Care and Use Committee of the Albert Einstein College of Medicine. The mouse lines were previously described: Rosa26 lox-stop-lox-DTA $\left(R 26^{\text {DTA }}\right.$ ) (Wu et al., 2006), TBX1-BAC (Funke et al., 2001), Tbx1 $1^{f x}$ (Arnold et al., 2006), Mesp1 ${ }^{\text {Cre }}$ (Saga et al., 1999), RCE

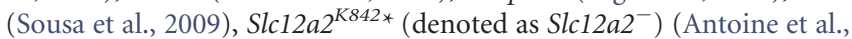
2013), Slc12a2 ${ }^{f x}$ (Antoine et al., 2013), Tbx ${ }^{\text {Cre }}$ (Huynh et al., 2007), and Pax2-Cre (Ohyama and Groves, 2004). Controls refer to littermates that do not carry Cre or are heterozygous for the mutant or floxed allele, except for the TBX1-BAC mutants where the littermate controls are wildtype. Both male and female mice were used for analyses (see Minor vestibular defects associate with anxiety-related behavior).

Open-field testing. Behavioral testing was conducted during the light cycle between 1200 and $1800 \mathrm{~h}$. Before testing, mice were acclimatized to the testing room for $2 \mathrm{~h}$. Animals were recorded in an open field chamber ( $25 \mathrm{~cm}$ length $\times 25$ width) for $30 \mathrm{~min}$. Total distance traveled and average velocity were quantified by the Viewer 2 tracking software (Bioserve). Rearing score was determined manually as the presence (1) or absence (0) of unsupported rearing during $30 \mathrm{~s}$ bins over $30 \mathrm{~min}$. Final rearing scores are totaled and represented as a number out of a maximum possible score of 60 . All behavioral equipment was cleaned between trials.

Elevated plus maze (EPM) test. Mice were placed into an elevated (60 $\mathrm{cm}$ ) plus-shaped maze containing two closed arms (with $15 \mathrm{~cm}$ high opaque walls) and two open arms (with small ledges to prevent falling). Each mouse was positioned in the center of the maze facing a closed arm for a $10 \mathrm{~min}$ trial. The Viewer 2 tracking software was used to quantify from recorded video the time spent, number of entries, total distance traveled, and average velocity in the center space, open arms, and closed arms.

Swim test. Mice were placed in a $2 \mathrm{~L}$ glass beaker with $\sim 36^{\circ} \mathrm{C}$ water. Mice were timed for $1 \mathrm{~min}$ for their ability to swim (i.e., resurface and maintain horizontal bodyline swimming). Mice that remained submerged and turned or tumbled beneath the surface were immediately rescued. The final swim score reflects the time out of a possible maximum score of $60 \mathrm{~s}$

Accelerated rotarod. Mice were positioned on a 3-cm-diameter elevated $(55 \mathrm{~cm})$ rod (Rotamex-5, Columbus Instruments). Acceleration was at $0.1 \mathrm{~cm} / \mathrm{s}$. The latency to fall was automatically recorded. Each animal was given 10 trials per day (daily score represented as the mean of the 10 trials), with an intertrial interval of $2 \mathrm{~min}$.

Histology. Tissue was prepared as described previously (Antoine et al., 2013). Antibodies included the following: rabbit anti-Slc12a2 (1:100, Proteintech Group), mouse anti-NeuN (1:100, Millipore), Hoechst 33342 (1:1000, Invitrogen), and rabbit anti-GFP (1:100, Invitrogen).

Vestibular sensory-evoked potential (VsEP) and auditory nerve brainstem evoked response (ABR) testing. Far-field compound action potential recordings from the vestibular (VsEP) and auditory (ABR) nerves and their respective central relays were recorded as described previously (Jones and Jones, 1999; Mock et al., 2011). Briefly, animals were anesthetized with a mixture of ketamine/xylazine $(18: 2 \mathrm{mg} / \mathrm{ml})$ injected intraperitoneally $(0.06-0.10 \mathrm{ml} / \mathrm{g}$ body weight). Recording electrodes were placed subcutaneously at the nuchal crest (noninverting), behind the right pinna (inverting) and at the hip (ground). Vestibular stimuli were calibrated linear jerk pulses presented to the cranium in the naso-occipital axis at levels ranging from 6 to $-18 \mathrm{~dB}$ re: $1.0 \mathrm{~g} / \mathrm{ms}$ (where $1.0 \mathrm{~g}=9.8 \mathrm{~m} / \mathrm{s}^{2}$ ). Auditory stimuli were calibrated tone bursts presented at the right ear at levels ranging from 110 to $25 \mathrm{~dB}$ peSPL). Stimuli were presented at a rate of 17 stimuli per second. Electroencephalographic activity was amplified $(200,000 \times)$, filtered $(300-3000 \mathrm{~Hz})$, digitized (10 $\mu$ s per point) and averaged (256 sweeps) to produce one averaged response waveform. All responses were replicated to show reproducibility. ABR and VsEP thresholds were identified from their intensity series and were defined as the stimulus level midway between the minimum level that produced a discernable response and the maximum level with no response.

Vestibular nucleus ablation. R26 $6^{\text {DTADTA }}$ mice (heterozygous null or homozygous wild-type for Slc12a2, each of which gave similar results) were anesthetized with isoflurane and stereotaxically injected with $0.5 \mu \mathrm{l}$ of AAV1-Cre virus (\#7010, Vector Biolabs) with a flow rate of $0.1 \mu \mathrm{l} / \mathrm{min}$ at bregma coordinates (in $\mathrm{mm}$ ): -5.9 posterior, 0.6 lateral, 4.4 depth. At the completion of the experiment, the accuracy of the injection site was confirmed histologically for every mouse.

\section{Results}

\section{Inner ear defects can cause motor hyperactivity}

As mouse models of inner ear dysfunction, we initially examined Slc12a2 null mutants (Slc12a2 ${ }^{-/-}$) (Antoine et al., 2013), Tbx1$B A C$ gain-of-function mutants, which overexpress TBX1 (Funke et al., 2001), and conditional loss-of-function Pax2-Cre; Tbx $1^{f x / f x}$ mutants, in which $T b x 1$ is lost from the otic placode, the anlagen of the inner ear, and the mid-hindbrain area (Ohyama and Groves, 2004). We first confirmed that all three mutants display morphological defects of the inner ear, including missing, ectopic, or collapsed membranes and sensory structures, indicative of auditory and VD (Delpire et al., 1999; Flagella et al., 1999; Pace et al., 2000; Funke et al., 2001; Arnold et al., 2006; Antoine et al., 2013) (Fig. 1). Consistent with the morphological defects, these mutants exhibit profound hearing loss (Flagella et al., 1999; Pace 

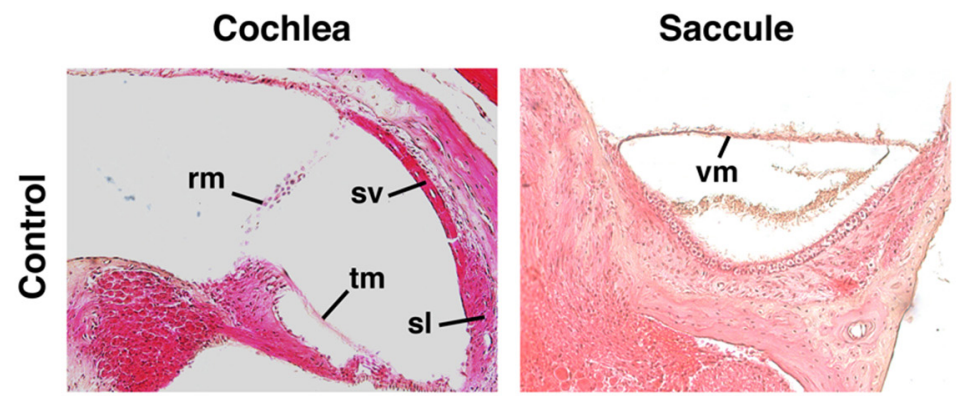

\section{Utricle and cristae}
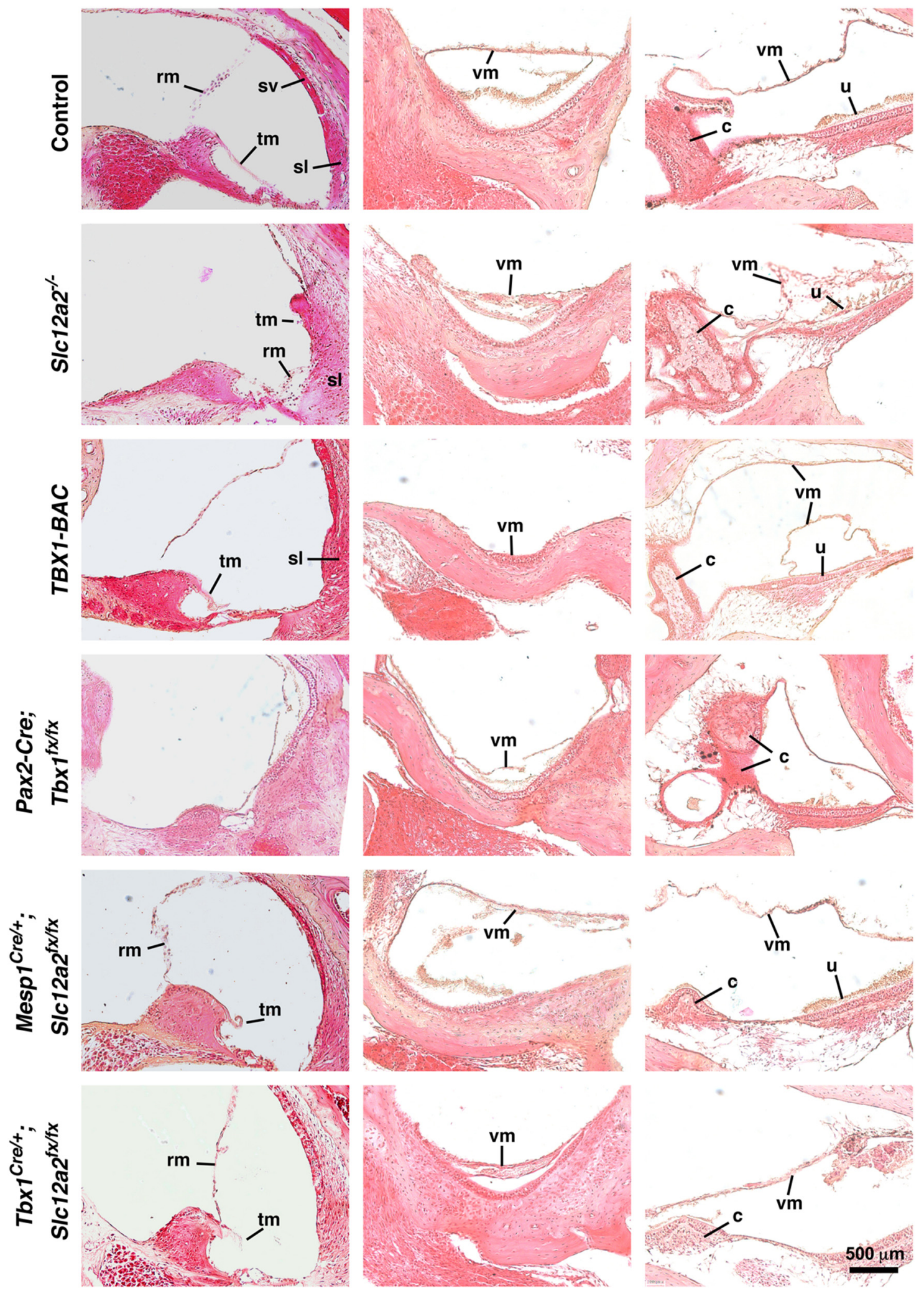

Figure 1. H\&E staining of the inner ear confirmed structural abnormalities. As examples, Reissner's membrane ( $\mathrm{rm}$ ) is collapsed in S/c12a2 ${ }^{-/-}$mutants, the spiral ligament (sl) is abnormal in TBX1-BAC mutants, the cochlea is undeveloped in Pax2-Cre; Tbx ${ }^{7 \times / x}$ mutants (arrow), the tectorial membrane (tm) is abnormal in Tbx ${ }^{C r e /+} ; S / c 12 a 2^{f x / f x}$ and $T B X 1-B A C$ mutants, the vestibular

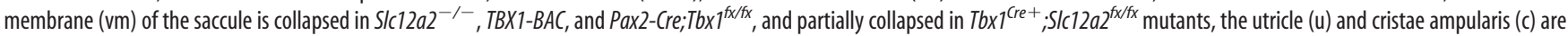

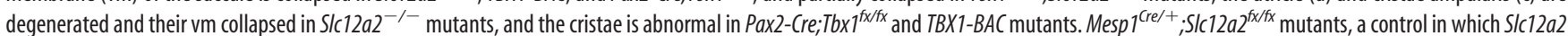
is recombined in the brain vasculature, show normal inner ear histology (see also Fig. $2 A, B$ ). Ectopic utricle VM in TBX1-BAC mutants. sv, Stria vascularis. $n=3$ or 4 animals/genotype. 


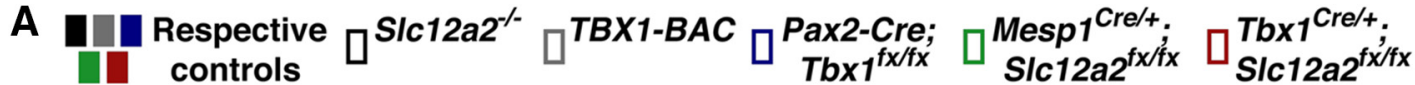
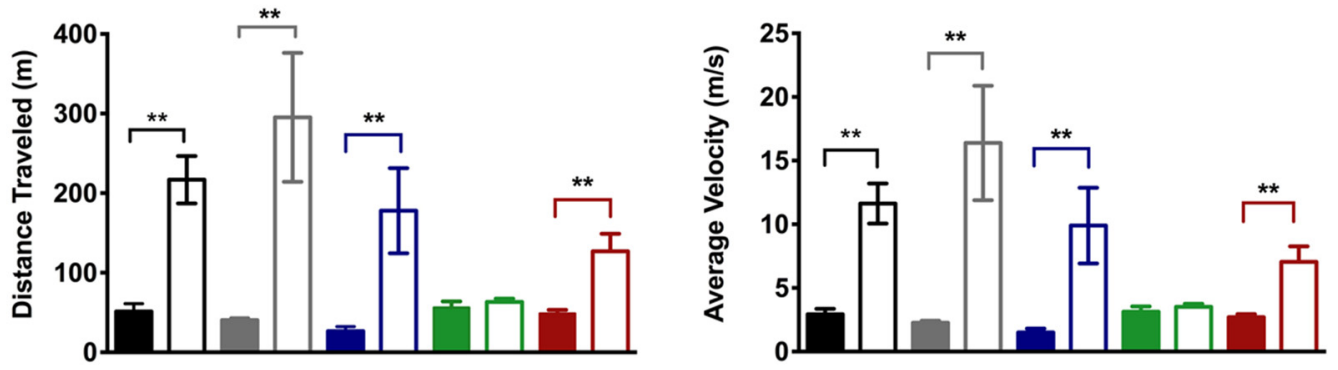

B
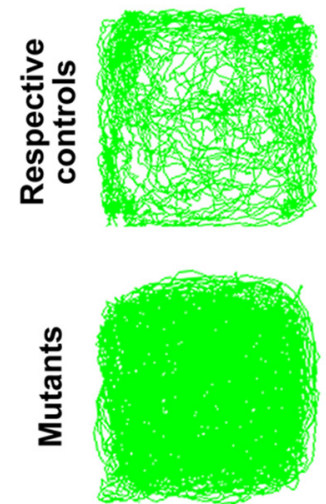

SIc12a2 ${ }^{-/-}$
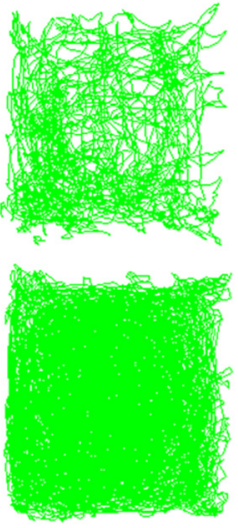

TBX1-BAC
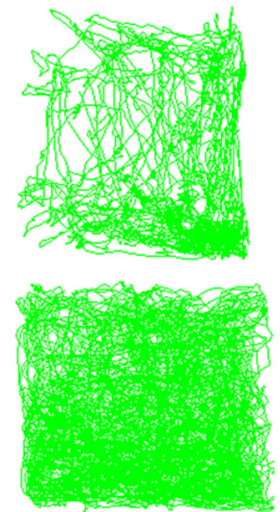

Pax2-Cre; $T b \times 1^{f x / f x}$
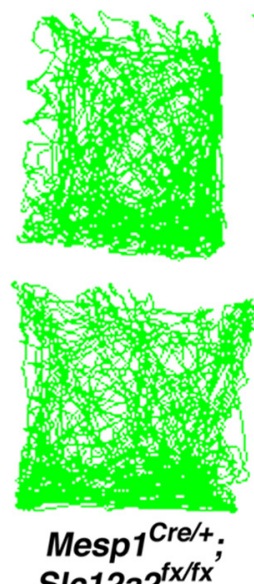
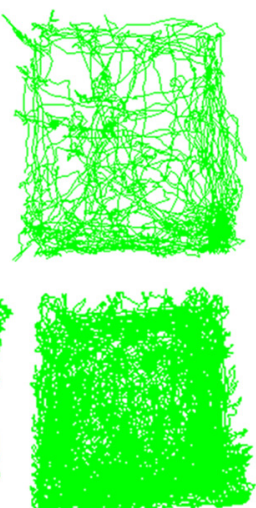

Tbx1 $\mathrm{Cre} /+$ SIc12a $2^{f x / f x}$

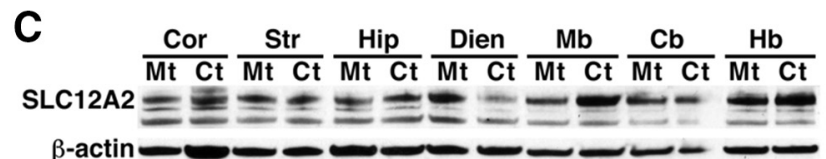

Mt: $\quad \mathrm{Tbx}^{\mathrm{Cre} /+} ; \mathrm{Slc12a2^{fx/fx }}$ Ct: SIc12a2 ${ }^{+/ f x}$

E

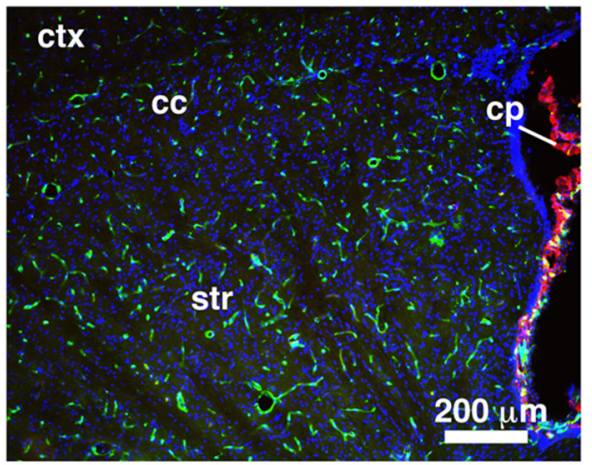

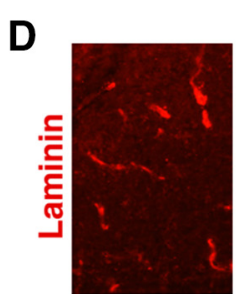

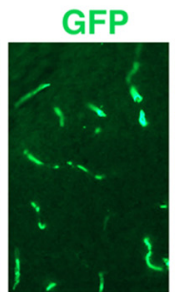

Merge
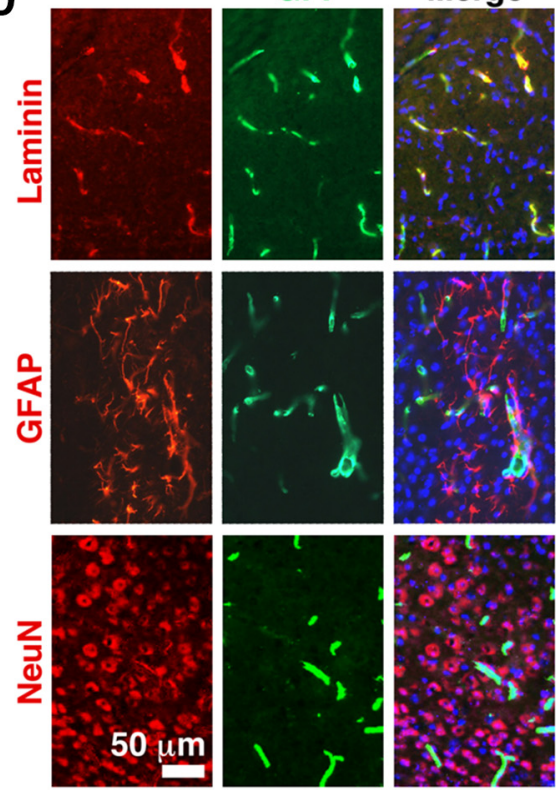

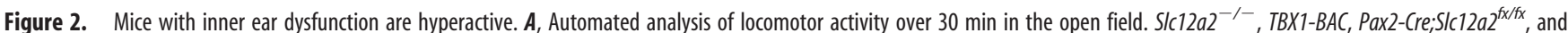



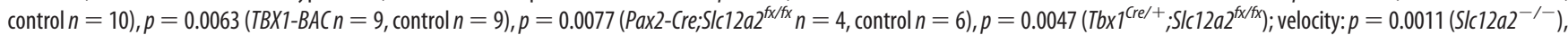

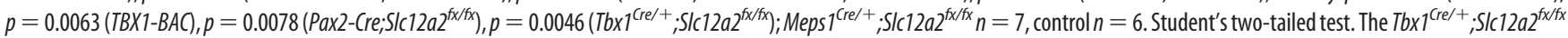
mutants combine 6-week-old mild and severe mutants (for details, see Fig. 4; Results). $\boldsymbol{B}$, Representative traces of locomotion. $\boldsymbol{C}$, Western blot showing maintained SLC12A2 protein in all brain regions examined in $\mathrm{Tb}_{\mathrm{b}} 1^{\mathrm{Cre} /+} ; \mathrm{S} / \mathrm{c} 12 \mathrm{a} 2^{\mathrm{fx} / \mathrm{fx}}$ mutants (Mt) and littermate controls (Ct). $\beta$-actin, loading control. Cb, Cerebellum; Cor, cortex; Dien, diencephalon; Hb, hindbrain; Hip, hippocampus; Mb, midbrain; Str, striatum. D. Fate mapping in $T_{b x} 1^{C r e /+} ; R C E$ mice showed recombination in blood vessels (laminin ${ }^{+}$) but not neurons $\left(\right.$NeuN $\left.{ }^{+}\right)$or glia $\left(G F A P{ }^{+}\right)$. Hoechst 33342 counterstain (blue). E, Mesp1 ${ }^{\text {rre/ }+} ;$ SIC12a $2^{\text {fx/fx}} ; R C E$ mice showed recombination in blood vessels (green) and retained expression of SLC12A2 (red) in the choroid plexus. Hoechst 33342 counterstain (blue). 



Figure 3. Recombination of the $S / C 12 a 2^{f x / f x}$ alleles driven by $T b x 1^{\text {Cre/ }+}$. $A$, Fate mapping of Tbx1-expressing cells using $T b x 1^{\text {Cre }}$ and an eGFP reporter (RCE) shows loss of SLC12A2 protein (green) in regions of the ear where $T_{b x} 7^{\text {Cre }}$ is expressed (red-labeled GFP). rm, Reissner's membrane; $s$, spiral limbus. B, Enlargement of area framed in $A$. C, Loss of the SLC12A2 protein (green) in regions of the saccule where $T b x 1^{\text {Cre }}$ is expressed (red). $N=4$ mice.

et al., 2000; Funke et al., 2001; Arnold et al., 2006; Antoine et al., 2013). In addition to inner ear dysfunction, Slc12a2 $2^{-1-}, T b \times 1-$ $B A C$, and Pax2-Cre; Tbx $1^{f x / f x}$ mutants display motor hyperactivity, with $\sim 4-5$ times greater distance traveled and velocity compared with their littermate controls (Fig. 2A,B).

To confirm that inner ear dysfunction alone can cause motor hyperactivity, we used the $T b x 1^{\text {Cre }}$ driver to delete Slc12a2 within the inner ear but not the neuronal and glial cells of the brain because $T b \times 1^{C r e}$ does not recombine within these cells (Huynh et al., 2007; Cioffi et al., 2014) (Figs. 2C-E, 3). Tbx1 ${ }^{\text {Cre }}$ does, however, recombine in the vascular endothelial cells of the brain (Fig. 2D) (Cioffi et al., 2014). To eliminate the possibility that loss of Slc12a2 from the brain vasculature causes hyperactivity, we used Mesp1 ${ }^{\text {Cre }}$ to delete Slc12a2 from the vascular endothelial cells (Saga et al., 1999) (Fig. 2E). Mesp1 $1^{\mathrm{Cre} /+} ;$; Slc12a2 $2^{f x / f x}$ mutants were not hyperactive (Fig. $2 A, B$ ). However, like Slc12a $2^{-/-}$null mice, $T b \times 1^{C r e /+} ; S l c 12 a 2^{f x / f x}$ mutants are hyperactive (Fig. 2A,B). Furthermore, although Pax2-Cre not only recombines in the ear (excluding some cells in the posterior cristae and in the canals) but also recombines in the midbrain, cerebellum, and olfactory bulb (Ohyama and Groves, 2004), the hyperactivity of Pax2-Cre; $T b x 1^{f x / f x}$ mutants should be the result of $T b x 1$ loss from the inner ear rather than the brain because $T b x 1$ is not expressed in neural and glial cells (Fig. 2D) (Cioffi et al., 2014). Together, the hyperactivity of

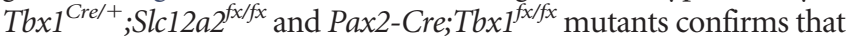
inner ear defects alone can cause motor hyperactivity.
Hyperactivity induced by inner ear dysfunction is coincident with severe vestibular rather than auditory failure

Mice with inner ear dysfunction usually exhibit locomotor hyperactivity by 3 weeks of age (Delpire et al., 1999; Pace et al.,

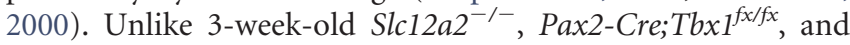
Tbx1-BAC mutant mice, which are hyperactive, 3-week-old

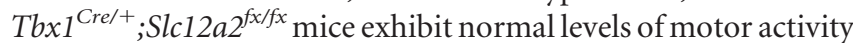
(Fig. 4A). However, by 6 weeks of age $\sim 65 \%$ (17 of 26 ) of $\mathrm{Tb} \times \mathrm{I}^{\mathrm{Cre} /+}$; Slc12a $2^{f x / f x}$ mice are hyperactive (denoted as "severe"), whereas the remaining fraction of mutants retain normal levels of activity (denoted as "mild") (Fig. 4A). Throughout this study, this categorization of mutants as "mild" or "severe" is based solely on their levels of locomotor activity at 6 weeks of age. Because inner ear defects caused hyperactivity, we reasoned that the difference between the severe and mild $\mathrm{Tb} \times 1^{\mathrm{Cre} /+} ; \mathrm{Slc} 12 a 2^{f x / f x}$ mutants was the degree and type (auditory or vestibular) of inner ear dysfunction. Auditory nerve brainstem evoked responses (ABR) in 3- to 4-week-old $\mathrm{Tb} \times 1^{\mathrm{Cre} /+} ; S l c 12 a 2^{f x / f x}$ mutants and their littermate controls revealed that all mutants, both mild and severe based on subsequent locomotor testing at 6 weeks, had profound sensorineural hearing loss (Fig. $4 B, C$ ). Because auditory function fails several weeks before the onset of hyperactivity in the severe mutants, the phenotypic distinction between severe and mild mutants was unlikely to be the degree of hearing loss.

Vestibular organ function was assessed behaviorally, histologically (for all vestibular organs), and by VsEP (for the maculae) in 

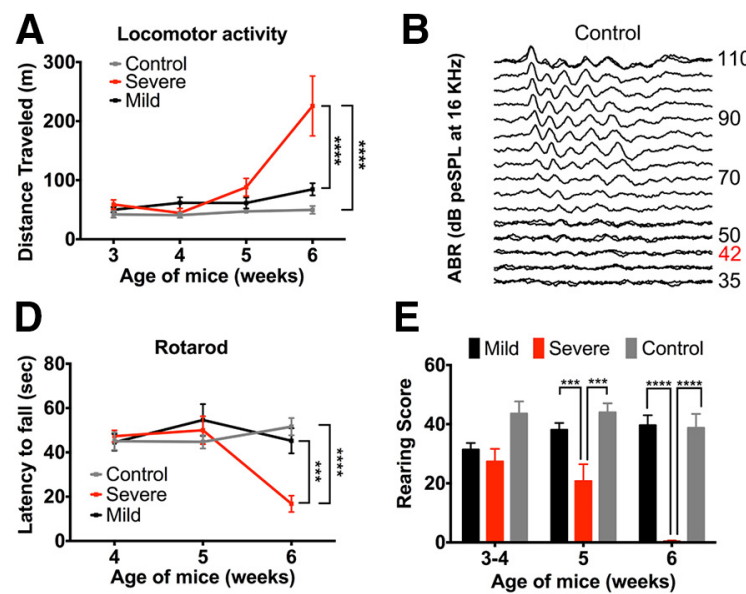

E
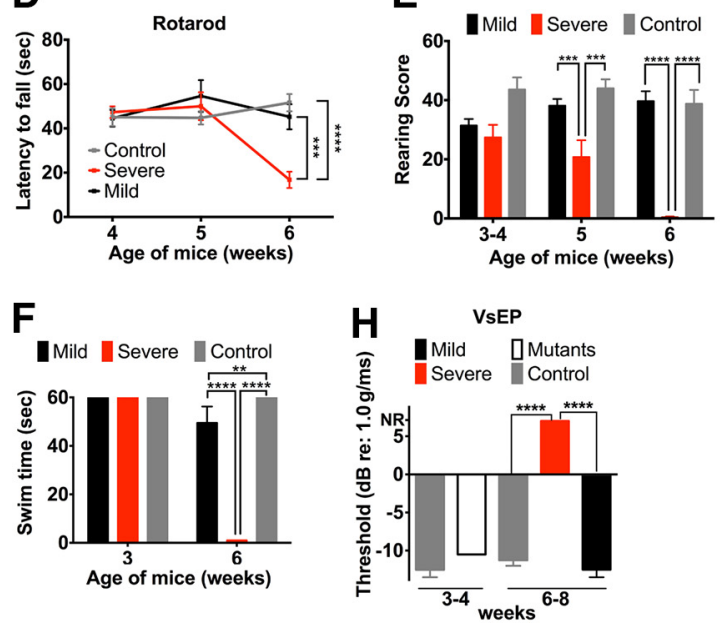


Figure 4. Hyperactivity induced by inner ear dysfunction is coincident with severe vestibular rather than auditory failure in $T b x 1^{C r e /+} ; S / c 12 a 2^{f x / f x}$ mutants. $A$, Severe, but not mild, mutants are hyperactive at 6 weeks. ${ }^{* * *} p<0.0001$. B, Example ABR traces showing response thresholds (red numbers). The first response peak is generated by the auditory primary afferents. Later peaks reflect brainstem auditory relays. Thresholds reflect the general sensitivity of the cochlea. $C$, ABR testing reveals profound hearing loss in 4-week-old mutants. dB peSPL, decibels peak equivalent sound pressure level. Data are mean \pm SEM ( $n=4$ or 5 mice/genotype). ${ }^{* *} p=0.0039$, Student's two-tailed test. ${ }^{* * *} p<0.0001$, Student's two-tailed test. $D$, Accelerated rotarod testing shows that only severe mutants have dynamic balance deficits at 6 weeks. Data are mean \pm SEM (severe mutants: $n=7$; mild mutants: $n=9$; control: $n=12$ ). ${ }^{* * *} p=0.0002$, two-way repeated-measures ANOVA with Tukey's multiple-comparisons test. ${ }^{* * *} p<0.0001$, two-way repeated-measures ANOVA with Tukey's multiple-comparisons test. $\boldsymbol{E}$, Severe mutants cannot rear by 6 weeks. Data are mean \pm SEM (severe mutants: $n=8$; mild mutants: $n=5$; control: $n=12$ ). $p=0.0003$ (mild vs severe). $p=0.0008$ (severe vs control). ${ }^{* * * *} p<0.0001$, two-way repeated-measures ANOVA with Tukey's multiple-comparisons test. $\boldsymbol{F}$, Mild mutants have subtle swimming deficits at 6 weeks, but severe mutants cannot swim. Data are mean \pm SEM (severe mutants: $n=7$; mild mutants: $n=6$; control: $n=12$ ). ${ }^{* *} p=0.0013$, two-way repeated-measures ANOVA with Tukey's multiple-comparisons test. ${ }^{* * *} p<0.0001$, two-way repeated-measures ANOVA with Tukey's multiple-comparisons test. $\boldsymbol{G}$, Although normal at 3 weeks in all mutants, the vestibular membrane (vm) is collapsed in severe mutants at 6 weeks. $N=3-6$ mice/genotype. $\boldsymbol{H}$, VsEP thresholds reflect the general sensitivity of the vestibular maculae (utricle and saccule) and indicate normal vestibular function in all mutants at 3 weeks and functional failure at 6 weeks only in severe mutants. NR, No response. Data are mean \pm SEM (severe mutants: $n=6$; mild mutants: $n=3$; control: $n=4$ ). ${ }^{* * *} p<0.0001$, Student's two-tailed test. I, ExampleVsEP traces showing the absence of response peaks 1 and 2 in severe mutants. The first response peak reflects neural activity of the vestibular primary afferents, whereas peak 2 and beyond represent brainstem relay nuclei.

$\mathrm{Tb}^{\mathrm{Cre} /+} ;$ Slc12a $2^{f x / f x}$ mutants and their littermate controls 3-6 weeks of age, with mutants classified as severe or mild by measuring locomotion at 6 weeks. Accelerated rotarod testing for balance and coordination showed that the mild mutants had normal dynamic balance, whereas the severe mutants had poor balance and failed to remain on the rod for any significant period of time (Fig. 4D). Unaided rearing on hind legs, a measure of postural stability and balance, revealed deficits in severe mutants at 5 weeks and a complete inability to rear at 6 weeks, whereas mild mutants and littermate controls retained normal rearing throughout the assessment period (Fig. 4E). Finally, a swim test that reflects vestibular processing necessary to remain oriented dorsal side up with head above water showed that the severe mutants could swim at 3 but not 6 weeks of age (Fig. $4 F$ ). The mild mutants could swim at 3 weeks and exhibited slight swimming deficits at 6 weeks, whereas their littermate controls could effortlessly swim at both time points (Fig. 4F). These behavioral tests suggest that the hyperactivity of severe $\mathrm{Tbx} 1^{\mathrm{Cre} /+} ;$ Slc12a2 $2^{f x / f x}$ mutants correlates with their level of VD. Moreover, although the mild mutants exhibited no hyperactivity at 6 weeks of age, they progressively became hyperactive between 16 and 23 weeks coincident with declining balance (Fig. $5 A-C$ ), further supporting that hyperactivity is the result of vestibular failure and to a great extent independent of the age of onset of vestibular failure.
Histological analysis confirmed that in severe mutants the membranes of all vestibular structures were partially or fully collapsed whereas in mild mutants the membranes were intact except for the vestibular membrane of the saccule, which was thicker at 6 weeks compared with controls (Figs. 1, 4G). As anatomical and functional abnormalities in the maculae are often associated with a lack of swimming ability (Ornitz et al., 1998), this subtle structural abnormality in the mild mutants could explain their suboptimal swimming at 6 weeks of age.

Finally, to more directly assess macula organ function, we recorded VsEPs. At 3-4 weeks of age, all mice had normal VsEP responses, but at 6-8 weeks, the severe $\mathrm{Tb}_{x 1^{\mathrm{Cr} /} /{ }^{+}} ; \mathrm{Slc} 12 a 2^{f x / f x} \mathrm{mu}-$ tants had no VsEP response whereas the mild mutants and their controls retained normal VsEP responses (Fig. 4H,I). Collectively, these results demonstrate that the onset of hyperactivity was coincident with vestibular failure.

\section{Central VD can cause hyperactivity}

Sensory information from the hair cells in the vestibular end organs is transduced to the CNS through the first-order neurons of Scarpa's ganglion that project to the brainstem vestibular nuclei (VN).

The loss of peripheral vestibular function results in the absence of input to the VN and, as a result, the CNS. Lesioning the 

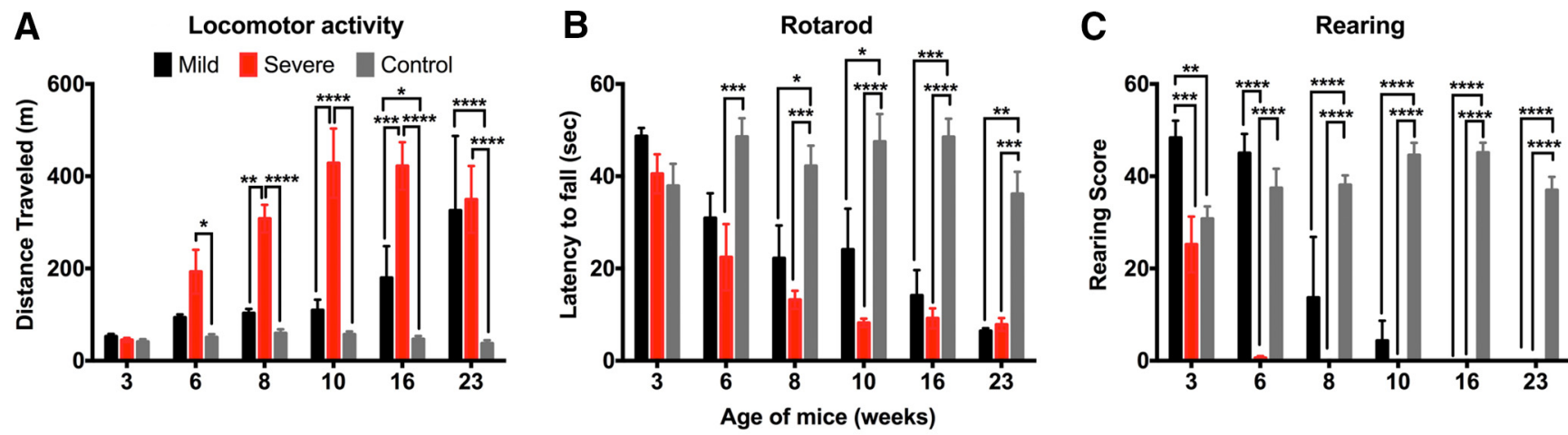

Figure 5. Hyperactivity induced by vestibular failure is independent of age in $T b x 1^{\text {Cre/+}} ;$ SIc $12 a 2^{f x / f x}$ mutants. A, Mild mutants become hyperactive between 16 and 23 weeks of age. Six weeks severe versus control: $p=0.0065 ; 8$ weeks severe versus mild: $p=0.0023 ; 16$ weeks mild versus control: $p=0.0458 ; 16$ weeks mild versus severe: $p=0.0003$. ${ }^{* * * *} p<0.0001 . B$, Accelerated rotarod testing showing dynamic balance in mild mutants fails gradually between 8 and 23 weeks of age. Six weeks severe versus control: $p=0.0007 ; 8$ weeks mild versus control: $p=0.0459$; severe versus control: $p=0.0001 ; 10$ weeks mild versus control: $p=0.0144 ; 16$ weeks mild versus control: $p=0.0002 ; 23$ weeks mild versus control: $p=0.0012 ;$ severe versus control: $p=0.0002$. ${ }^{* * * *} p<0.0001$. C, Mild mutants become unable to stand on their hind legs by 16 weeks. Data are mean $\pm \mathrm{SEM}$ (severe mutants $n=5$, mild mutants $n=3$, control $n=9$ ). Three weeks mild versus severe: $p=0.0006$; mild versus control: $p=0.0055 .{ }^{* * *} p<0.0001$, two-way repeated-measures ANOVA with Bonferroni's multiple-comparisons test.

VN should therefore recapitulate the hyperactivity phenotype induced by peripheral sensory dysfunction. VN function was abolished via the stereotaxic injection of an AAV1-Cre virus into the VN of mice homozygous for a Rosa26 allele driving conditional expression of the diphtheria toxin A $\left(R 26^{D T A / D T A}\right)$ (Wu et al., 2006, Sousa et al., 2009). Efficient AAV1-Cremediated recombination of floxed alleles is detected in vivo within 2 weeks after administration (Rovó et al., 2014). Immunohistochemical staining for the neuronal nuclear marker (NeuN) indicated that a significant loss of $\mathrm{VN}$ neurons had occurred by 2 weeks after injection (Fig. 6A). Based on NeuN staining, all VN targeted mice had lost the majority of neurons in the medial vestibular nucleus (the largest vestibular subnucleus with projections to the thalamus) and a significant fraction (approximately half) of neurons in the lateral, superior, and inferior subnuclei. $R 26^{D T A / D T A}$ mice with lesions to the VN became hyperactive at $10-11 \mathrm{~d}$ after injection, whereas control animals with lesions targeting adjacent areas maintained normal levels of motor activity (Fig. 6B), indicating that central as well as peripheral VD can cause hyperactivity.

\section{Minor vestibular defects associate with anxiety-} related behavior

A biological explanation is lacking as to why within the $45 \%-50 \%$ of deaf children with behavioral abnormalities exhibit externalizing symptoms such as hyperactivity and others internalizing symptoms such as anxiety (Hindley, 1994, 2000; Hindley et al., 1994; van Eldik et al., 2004; van Gent et al., 2007). To determine a possible relationship between inner ear dysfunction and anxiety

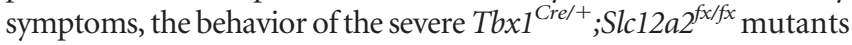
at 3,5, and 6 weeks of age was examined in the EPM. Mice have an innate preference for the dark enclosed arms of the EPM rather than the lit open arms, which are anxiogenic (Walf and Frye,
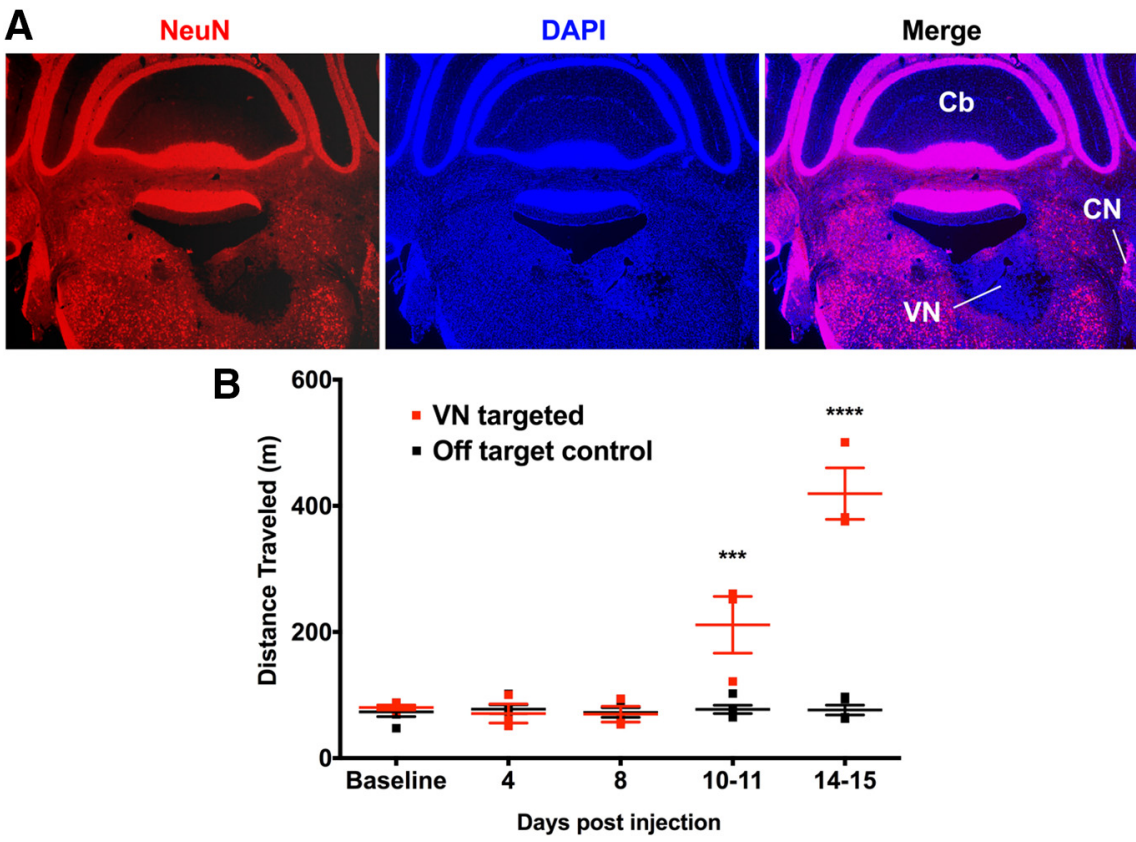

Figure 6. Hyperactivity is induced by lesioning the vestibular nucleus. A, Coronal section showing a unilateral AAV-Cre-induced lesion (loss of NeuN-labeled neurons, red) in the VN of R26 $6^{\text {DTA/DTA }}$ mice. Hoechst-33342 counterstain (blue). CN, Cochlear nucleus; $\mathrm{Cb}$, cerebellum. $\boldsymbol{B}$, Correctly targeted VN-lesioned mice become hyperactive. Controls are lesions from shallower injections of virus into the ventral cerebellum immediately adjacent and dorsal to the VN. Data are mean \pm SEM $(n=3$ VN targeted mice, $n=5$ controls). ${ }^{* *} p=0.0003$, two-way repeated-measures ANOVA with Tukey multiple-comparisons test. ${ }^{* * * *} p<0.0001$, two-way repeated-measures ANOVA with Tukey multiple-comparisons test.

2007). We found that 3 -week-old mutants, which have profound hearing loss but normal vestibular function, do not behave differently in the EPM than their littermate controls (Fig. $7 A, B$ ). However, at 5 weeks, when vestibular defects are just beginning to manifest, mutants favor the closed arms over the open arms compared with their littermate controls (Fig. $7 A, B$ ), indicating that minor vestibular defects are associated with increased anxiety-related behavior. Unexpectedly, at 6 weeks, anxiety-related behavior had subsided in the severe $\mathrm{Tbx} \mathrm{I}^{\mathrm{Cre} /+} ; S l c 12 a 2^{\mathrm{fx} / \mathrm{fx}}$ mutants, which by this time have VD and hyperactivity (Fig. 7A-E). Notably, at 6 weeks, these $\mathrm{Tb}_{x 1}{ }^{\mathrm{Cre} /+} ;$;lc12a2 ${ }^{f x / f x}$ mutants did not venture out as far in the open arms (Fig. $7 B, F$ ), which could reflect an increased aversion to the open spaces due to their balance deficits. 
A


5 weeks (mild VD)

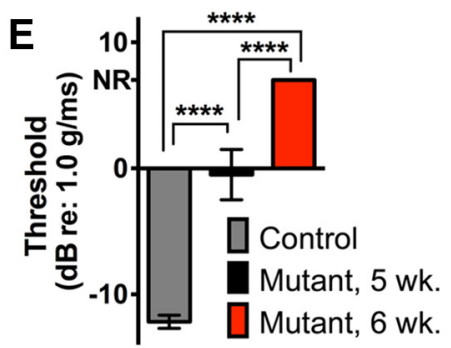

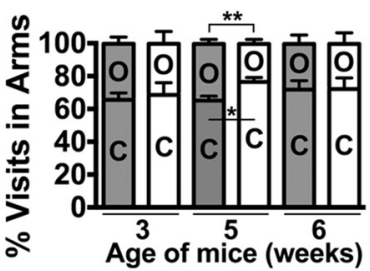
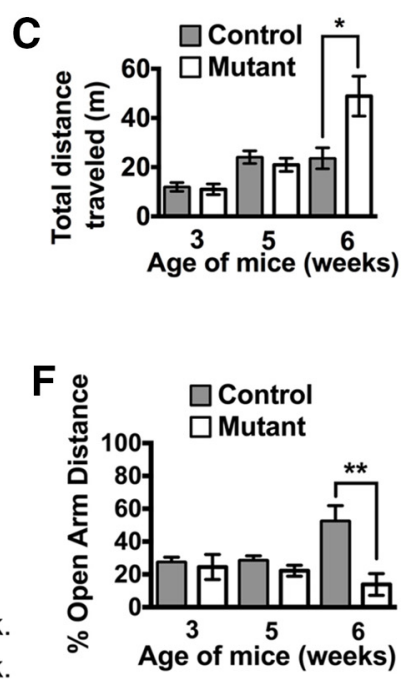

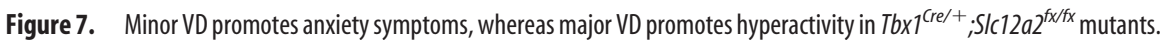
$A$, EPM testing shows that 3-week-old mutants exhibit normal anxiety. At 5 weeks, severe mutants begin showing subtle VD and spend more time in and make more visits to the closed arms. At 6 weeks, severe mutants have extensive VD and resume normal anxiety levels. Data are mean \pm SEM ( $n=3$ or 4 mice/genotype at 3 weeks; $n=8$ or 9 mice/genotype at 5 weeks; $n=6$ mice/genotype at 6 weeks). Five weeks in arms: ${ }^{*} p=0.0126,{ }^{* * *} p=0.0005 ; 5$ week visits in arms: ${ }^{* *} p=0.01$, Student's two-tailed test. $\boldsymbol{B}$, Representative EPM traces of control and mutants. $\boldsymbol{C}$, Total distance traveled during EPM testing. Severe mutants in $A$ become hyperactive at 6 weeks. Data are mean \pm SEM ( $n=3$ or 4 mice/genotype at 3 weeks; $n=8$ or 9 mice/genotype at 5 weeks; $n=6$ mice/genotype at 6 weeks). ${ }^{*} p=0.0202$, Student's two-tailed test. $\boldsymbol{D}, \boldsymbol{E}$, Rearing analysis (D) and VsEPs $(\boldsymbol{E})$ indicate minor VD in mutants at 5 weeks and major VD at 6 weeks. NR, No response. Data are mean \pm SEM (D; control: $n=17 ; 5$ week mutant: $n=8 ; 6$ week mutant: $n=7 ; E ;$ control: $n=9 ; 5$ week mutant: $n=3 ; 6$ week mutant: $n=6){ }^{*} p=0.0329$, one-way ANOVA with Tukey multiple-comparisons test. ${ }^{* * *} p=0.0007$, one-way ANOVA with Tukey multiple-comparisons test.

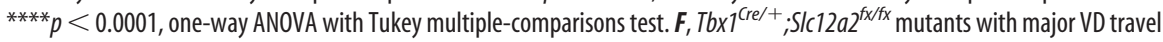
significantly shorter distances in the open arms of the EPM at 6 weeks of age. Data are mean \pm SEM ( $n=3$ or 4 mice/genotype at 3 weeks; $n=8$ or 9 mice/genotype at 5 weeks; $n=6$ mice/genotype at 6 weeks). ${ }^{* *} p=0.0017$, Student's two-tailed test.

There is a vast literature that reports sex differences in levels of anxiety and locomotor behavior. The findings investigating the effect of sex on the display of psychopathothogy with deafness in humans, however, are currently inconclusive (Brown and Cornes, 2015). Several studies have found that deaf and hard of hearing boys exhibited a higher rate of aggression (Cartledge et al., 1991; Sinkkonen, 1994), hyperactivity (Hindley and Kroll, 1998), and total mental (emotional, conduct, hyperactivity/inattention, peer and prosocial) problems than deaf and hard of hearing girls (Mejstad et al., 2009). Additionally, deaf and hard of hearing girls were found to self-report significantly higher incidences of emotional problems than deaf and hard of hearing boys (van Gent et al., 2007). In contrast, several researchers found an elevated prevalence of emotional and behavioral problems among deaf individuals but detected no significant differences in the percentages of deaf boys and deaf girls afflicted with emotional (including anxiety and mood disorders) and behavioral problems (including hyperactivity disorder) (van Eldik, 2004; van Eldik, 2005; van Gent et al., 2007).

Nevertheless, given the observed sex differences in levels of anxiety and locomotor behavior in other contexts, we analyzed our data separately by sex to address the possibility that inner ear-induced levels of anxiety and hyperactivity differed between the sexes in the context of our inner ear mouse models. We found that there are no significant sex differences in the display of the anxiety phenotype caused by inner ear dysfunction. $\mathrm{Tb} x 1^{\mathrm{Cre} /+}$; Slc12a $2^{f x / f x}$ females and males spent similar times in the open and closed arms of the EPM (females vs males: closed arm time: $61.55 \pm 2.996 \%$ vs $50.3 \pm 6.28 \%, p=0.15$; open arm time: $11.09 \pm 1.95 \%$ vs $20.69 \pm 8.86 \%, p=$ $0.34, n=7$ and $n=8$, respectively) and made a comparable number of visits to the open and closed arms of the EPM (females vs males: closed arm visits: $78.45 \pm$ $3.59 \%$ vs $71.11 \pm 5.66 \%, p=0.31$; open arm visits: $21.55 \pm 3.586 \%$ vs $28.89 \pm$ $5.657 \%, p=0.31, n=7$ and $n=8$, respectively). We also did not observe significant sex differences in the display of hyperactivity induced by inner ear dysfunction. The mean distance traveled during the testing period for $\mathrm{Tbxl}^{\mathrm{Cre} /+} ;$ Slc12a2 ${ }^{f x / f x}$ females versus males was $120.7 \pm 27.11 \mathrm{~m}$ versus $146.8 \pm 28.75 \mathrm{~m} ; p=0.59, n=7$ females and $n=16$ males/genotype. Likewise, the mean distance traveled during the testing period for Slc12a2 $2^{-1-}$ females versus males was $247 \pm 54.27 \mathrm{~m}$ versus $213.2 \pm 38.78 \mathrm{~m} ; p=0.61, n=14$ females and $n=11$ males/genotype.

\section{Discussion}

Together, our results suggest a dichotomy in the symptoms associated with vestibular defects, such that minor defects are associated with increased anxiety-related behavior and major vestibular defects cause hyperactivity, often indicative of disorders, such as ADHD (Fig. 8A). Based on previous results of the incidence of normal, mild, and severe VD in children with severe hearing loss due to different causes (Arnvig, 1955), we predict that anxiety-related and hyperactive symptoms due to mild and severe VDs, respectively, will be most prevalent in populations of children where hearing loss is due to infection (Fig. 8B).

Using distinct mouse models in which either Slc12a2 or Tbx1 are deleted tissue-specifically, we extend previous findings indicating that inner ear dysfunction causes hyperactivity (Antoine et al., 2013). Distinguishing the contribution of auditory versus vestibular failure to hyperactivity in genetic mouse models of inner ear dysfunction had been hindered by the concomitant failure of both functions by the time mice are ambulatory. Additionally, the use of ototoxic drugs or surgical methods to produce "selective" insults to either the auditory or vestibular systems frequently damaged both (Smouha and Inouye, 1999). Here, we provide evidence that vestibular rather than auditory dysfunction is a biological factor that causes hyperactivity. Because lesions of the VN can also cause hyperactivity, loss of vestibular function alone, rather than the combined loss of auditory and vestibular function, is likely sufficient in promoting hyperactivity. Moreover, our results suggest that the severity rather than the age of 
A

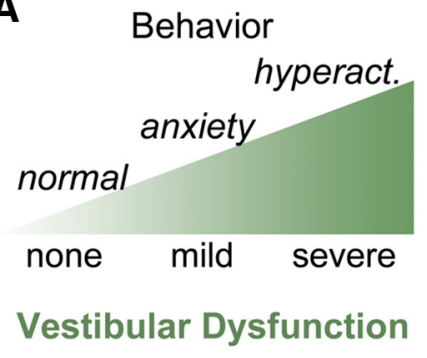

B Inherited $(n=128)$

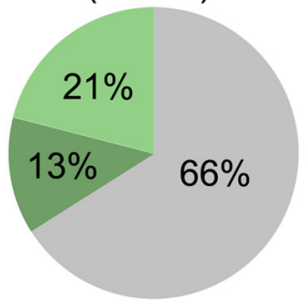

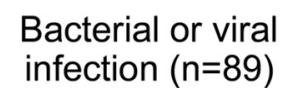

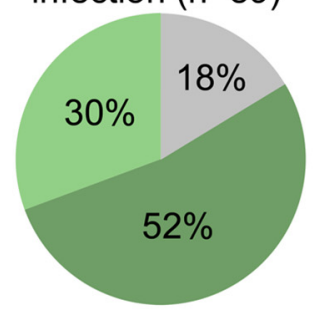

Injury, anoxaemia, severe prematurity $(n=61)$

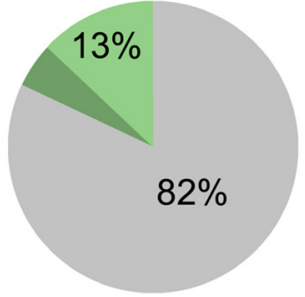

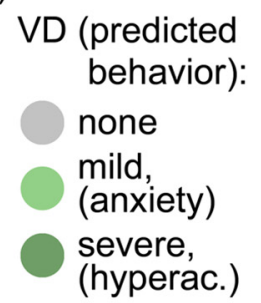

Figure 8. Predicted relation between VD and behavior. $\boldsymbol{A}$, Summary illustration of the proposed association between VD and behavior. $\boldsymbol{B}$, Predicted prevalence of anxiety-related and hyperactivity symptoms in hearing-impaired children categorized by etiology of hearing loss and based on previous percentages of comorbid VD (Arnvig, 1955).

onset of VD predicts the behavioral outcome, either hyperactivity or anxiety-related behavior. These findings add to our understanding of the biological factors that influence the spectrum of behaviors that occur with inner ear defects.

\section{Connecting VD to hyperactivity and anxiety}

Anatomical tracing studies have revealed several vestibulothalamic projections that can potentially function to modulate the activity of the motor cortex and striatum, two main effectors of movement. Dense projections from all parts of the $\mathrm{VN}$ in the rat, cat, and monkey reach the ventroanterior to ventrolateral thalamic nuclear complex and indirectly connect to the striatum (Shiroyama et al., 1999; for review, see Stiles and Smith, 2015).

Surprisingly, we found that the severe $\mathrm{Tb} \times 1^{\mathrm{Cre} /+} ; \mathrm{Slc12a2^{fx/fx }}$ mutants exhibited an increase in anxiety-related behavior at 5 weeks when vestibular function was reduced but not at 3 or 6 weeks, when vestibular function was normal or absent, respectively. It is unclear why anxiety levels become elevated with reduced vestibular function and lowered with a more complete loss of vestibular function. We suspect that these observations support a role of the vestibular system in activating a sustained anxiety or fear response to an abnormal or sudden alteration in the stability of body motion, equilibrium, or spatial orientation (Kalueff et al., 2008). Hence, in the absence of vestibular function, this response is impaired, whereas with reduced vestibular function and increased disequilibrium this system is hyperactivated. This proposed function, which links the peripheral vestibular system with the fear or anxiety networks of the brain could help explain why reduced function of the vestibular system in humans is frequently associated with several subtypes of anxiety, such as generalized anxiety, panic attacks, phobia, and post-traumatic stress (Eagger et al., 1992; Godemann et al., 2005; Kalueff et al., 2008; Best et al., 2009). Uncovering the neuro-anatomical connections that link vestibular input to the emotion processing systems will further our understanding of how vestibular hypofunction might promote anxiety disorders.

\section{Challenges diagnosing VD}

The findings presented here emphasize a need for testing vestibular function in individuals, especially children, with a history of inner ear problems and displays of hyperactivity or anxiety. Diagnosing VD can be difficult because it typically involves the use of techniques, such as electronystagmography, videonystagmography, and computerized dynamic posturography, which are not widely used or easily accessible. Adding to the complication of diagnosis is the fact that some symptoms, such as dizziness, are not unique to VD and can manifest with a variety of medical conditions, such as cardiovascular, visual, autonomic, psycho- logical, or neurological disorders (Agrawal et al., 2009). For example, congenital and perinatal VD in children and infants is frequently misdiagnosed as cerebellar ataxia, cerebral palsy, or brain damage due to shared neurological signs, such as hypotonia, floppiness, ataxia, and shuffling (Kaga et al., 1988; Admiraal and Huygen, 1997; Kaga, 1999). Furthermore, the diagnosis of vestibular disorders in children may often be overlooked as children may not self-report common symptoms, such as vertigo and imbalance, due to their lack of understanding of such percepts (Angeli, 2003; Weiss and Phillips, 2006; Suarez et al., 2007). Nonetheless, despite these challenges, VD should not remain undiagnosed or untreated because its presence may be directly responsible for hyperactivity or anxiety symptoms in children, especially those with profound hearing loss.

\section{References}

Admiraal RJ, Huygen PL (1997) Vestibular areflexia as a cause of delayed motor skill development in children with the CHARGE association. Int J Pediatr Otorhinolaryngol 39:205-222. CrossRef Medline

Agrawal Y, Carey JP, Della Santina CC, Schubert MC, Minor LB (2009) Disorders of balance and vestibular function in US adults: data from the National Health and Nutrition Examination Survey, 2001-2004. Arch Intern Med 169:938-944. CrossRef Medline

Angeli S (2003) Value of vestibular testing in young children with sensorineural hearing loss. Arch Otolaryngol Head Neck Surg 129:478-482. CrossRef Medline

Antoine MW, Hübner CA, Arezzo JC, Hébert JM (2013) A causative link between inner ear defects and long-term striatal dysfunction. Science 341:1120-1123. CrossRef Medline

Arnold JS, Werling U, Braunstein EM, Liao J, Nowotschin S, Edelmann W, Hebert JM, Morrow BE (2006) Inactivation of Tbx1 in the pharyngeal endoderm results in 22q11DS malformations. Development 133:977987. CrossRef Medline

Arnvig J (1955) Vestibular function in deafness and severe hardness of hearing. Acta Otolaryngol 45:283-288. CrossRef Medline

Best C, Eckhardt-Henn A, Tschan R, Dieterich M (2009) Psychiatric morbidity and comorbidity in different vestibular vertigo syndromes. J Neurol 256:58-65. CrossRef Medline

Brown PM, Cornes A (2015) Mental health of deaf and hard-of-hearing adolescents: what the students say. J Deaf Stud Deaf Educ 20:75-81. CrossRef Medline

Cartledge G, Paul P, Jackson D, Cochran LL (1991) Teachers' perceptions of the social skills of adolescents with hearing impairment in residential and public school settings. Remedial Special Educ 12:34-39. CrossRef

Cioffi S, Martucciello S, Fulcoli FG, Bilio M, Ferrentino R, Nusco E, Illingworth E (2014) Tbx1 regulates brain vascularization. Hum Mol Genet 23:78-89. CrossRef Medline

Cushing SL, Papsin BC, Rutka JA, James AL, Gordon KA (2008) Evidence of vestibular and balance dysfunction in children with profound sensorineural hearing loss using cochlear implants. Laryngoscope 118:18141823. CrossRef Medline

Delpire E, Lu J, England R, Dull C, Thorne T (1999) Deafness and imbalance associated with inactivation of the secretory $\mathrm{Na}-\mathrm{K}-2 \mathrm{Cl}$ co-transporter. Nat Gen 22:192-195. CrossRef Medline 
Digilio MC, Pacifico C, Tieri L, Marino B, Giannotti A, Dallapiccola B (1999) Audiological findings in patients with microdeletion 22Qll (Di George/Velocardiofacial Syndrome). Br J Audiol 33:329-333. CrossRef Medline

Dodson KM, Blanton SH, Welch KO, Norris VW, Nuzzo RL, Wegelin JA, Marin RS, Nance WE, Pandya A, Arnos KS (2011) Vestibular dysfunction in DFNB1 deafness. Am J Med Gen 155:993-1000. CrossRef Medline

Eagger S, Luxon LM, Davies RA, Coelho A, Ron MA (1992) Psychiatric morbidity in patients with peripheral vestibular disorder: a clinical and neuro-otological study. J Neurol Neurosurg Psychiatry 55:383-387. CrossRef Medline

Emanuel BS, McDonald-McGinn D, Saitta SC, Zackai EH (2001) The 22q11.2 deletion syndrome. Adv Pediatr 48:39-73. Medline

Flagella M, Clarke LL, Miller ML, Erway LC, Giannella RA, Andringa A, Gawenis LR, Kramer J, Duffy JJ, Doetschman T, Lorenz JN, Yamoah EN, Cardell EL, Shull GE (1999) Mice lacking the basolateral Na-K-2Cl cotransporter have impaired epithelial chloride secretion and are profoundly deaf. J Biol Chem 274:26946-26955. CrossRef Medline

Freyer L, Nowotschin S, Pirity MK, Baldini A, Morrow BE (2013) Conditional and constitutive expression of a Tbx1-GFP fusion protein in mice. BMC Dev Biol 13:33. CrossRef Medline

Funke B, Epstein JA, Kochilas LK, Lu MM, Pandita RK, Liao J, Bauerndistel R, Schüler T, Schorle H, Brown MC, Adams J, Morrow BE (2001) Mice overexpressing genes from the 22q11 region deleted in velo-cardio-facial syndrome/DiGeorge syndrome have middle and inner ear defects. Hum Mol Gen 10:2549-2556. CrossRef Medline

Furth HG (1966) Thinking without language: psychological implications of deafness. New York: Free.

Godemann F, Siefert K, Hantschke-Brüggemann M, Neu P, Seidl R, Ströhle A (2005) What accounts for vertigo one year after neuritis vestibularis: anxiety or a dysfunctional vestibular organ? J Psychiatr Res 39:529-534. CrossRef Medline

Hindley P (1994) Signs of feeling: a prevalence study of psychiatric disorder in deaf and partially hearing children and adolescents. London: Royal National Institute for Deaf People.

Hindley P (2000) Child and adolescent psychiatry. In: Hindley P, Kitson N (eds). Mental health and deafness, pp 42-74. London: Whurr.

Hindley P, Kroll L (1998) Theoretical and epidemiological aspects of attention deficit and overactivity in deaf children. J Deaf Stud Deaf Educ 3:6472. CrossRef Medline

Hindley P, Hill PD, McGuigan S, Kitson N (1994) Psychiatric disorder in deaf and hearing impaired children and young people: a prevalence study. J Psychiatr Psychol 35:917-934. CrossRef Medline

Huynh T, Chen L, Terrell P, Baldini A (2007) A fate map of Tbx1 expressing cells reveals heterogeneity in the second cardiac field. Genesis 45:470475. CrossRef Medline

Jones TA, Jones SM (1999) Short latency compound action potentials from mammalian gravity receptor organs. Hear Res 136:75-85. CrossRef Medline

Kaga K (1999) Vestibular compensation in infants and children with congenital and acquired vestibular loss in both ears. Int J Pediatr Otorhinolaryngol 49:215-224. CrossRef Medline

Kaga K, Maeda H, Suzuki J (1988) Development of righting reflexes, gross motor functions and balance in infants with labyrinth hypoactivity with or without mental retardation. Adv Otorhinolaryngol 41:152-161. Medline

Kalueff AV, Ishikawa K, Griffith AJ (2008) Anxiety and otovestibular disorders: linking behavioral phenotypes in men and mice. Behav Brain Res 186:1-11. CrossRef Medline

Lesser SR, Easser BR (1972) Personality differences in the perceptually handicapped. J Am Acad Child Psychiatry 11:458 - 466. CrossRef Medline

Liao J, Kochilas L, Nowotschin S, Arnold JS, Aggarwal VS, Epstein JA, Brown MC, Adams J, Morrow BE (2004) Full spectrum of malformations in velo-cardio-facial syndrome/DiGeorge syndrome mouse models by altering Tbx1 dosage. Hum Mol Gen 13:1577-1585. CrossRef Medline

Mejstad L, Heiling K, Svedin CG (2009) Mental health and self-image among deaf and hard of hearing children. Am Ann Deaf 153:504-515. CrossRef Medline

Mock B, Jones TA, Jones SM (2011) Gravity receptor aging in the CBA/CaJ strain: a comparison to auditory aging. J Assoc Res Otolaryngol 12:173183. CrossRef Medline

Ogata T, Niihori T, Tanaka N, Kawai M, Nagashima T, Funayama R, Nakayama K, Nakashima S, Kato F, Fukami M, Aoki Y, Matsubara Y (2014)
TBX1 mutation identified by exome sequencing in a Japanese family with 22q11.2 deletion syndrome-like craniofacial features and hypocalcemia. PLoS One 17:e91598. CrossRef Medline

Ohyama T, Groves AK (2004) Generation of Pax2-Cre mice by modification of a Pax2 bacterial artificial chromosome. Genesis 38:195-199. CrossRef Medline

O’Reilly R, Grindle C, Zwicky EF, Morlet T (2011) Development of the vestibular system and balance function: differential diagnosis in the pediatric population. Otolaryngol Clin North Am 44:251-271. CrossRef Medline

Ornitz DM, Bohne BA, Thalmann I, Harding GW, Thalmann R (1998) Otoconial agenesis in tilted mutant mice. Hear Res 122:60-70. CrossRef Medline

Pace AJ, Lee E, Athirakul K, Coffman TM, O’Brien DA, Koller BH (2000) Failure of spermatogenesis in mouse lines deficient in the $\mathrm{Na}-\mathrm{K}-2 \mathrm{Cl}-$ cotransporter. J Clin Invest 105:441-450. CrossRef Medline

Reivich RS, Rothrock IA (1972) Behavior problems of deaf children and adolescents. J Speech Hear Res 15:93-104. CrossRef Medline

Reyes MR, LeBlanc EM, Bassila MK (1999) Hearing loss and otitis media in velo-cardio-facial syndrome. Int J Pediatr Otorhinolaryngol 47:227-233. CrossRef Medline

Rovó Z, Mátyás F, Barthó P, Slézia A, Lecci S, Pellegrini C, Astori S, Dávid C, Hangya B, Lüthi A, Acsády L (2014) Phasic, nonsynaptic GABA-a receptormediated inhibition entrains thalamocortical oscillations. J Neurosci 34: 7137-7147. CrossRef Medline

Saga Y, Miyagawa-Tomita S, Takagi A, Kitajima S, Miyazaki Ji, Inoue T (1999) Mespl is expressed in the heart precursor cells and required for the formation of a single heart tube. Development 126:3437-3447. Medline

Schneider M, Debbané M, Bassett AS, Chow EW, Fung WL, van den Bree M, Owen M, Murphy KC, Niarchou M, Kates WR, Antshel KM, Fremont W, McDonald-McGinn DM, Gur RE, Zackai EH, Vorstman J, Duifff SN, Klaassen PW, Swillen A, et al. (2014) Psychiatric disorders from childhood to adulthood in 22q11.2 deletion syndrome: results from the international consortium on brain and behavior in 22q11.2 deletion syndrome. Am J Psychiatry 171:627-639. CrossRef Medline

Shiroyama T, Kayahara T, Yasui Y, Nomura J, Nakano K (1999) Projections of the vestibular nuclei to the thalamus in the rat: a Phaseolus vulgaris leucoagglutinin study. J Comp Neurol 407:318-332. CrossRef Medline

Sinkkonen J (1994) Hearing impairment, communication, and personality development. Helsinki: University of Helsinki, Department of Child Psychiatry.

Smouha EE, Inouye M (1999) Partial labyrinthectomy with hearing preservation: frequency-specific data using tone-burst auditory brain stem response. Otolaryngol Head Neck Surg 120:146-152. CrossRef Medline

Sousa VH, Miyoshi G, Hjerling-Leffler J, Karayannis T, Fishell G (2009) Characterization of Nkx6-2-derived neocortical interneuron lineages. Cereb Cortex 19 [Suppl 1]:i1- i10.

Stiles L, Smith PF (2015) The vestibular-basal ganglia connection: balancing motor control. Brain Res 1597:180-188. CrossRef Medline

Suarez H, Angeli S, Suarez A, Rosales B, Carrera X, Alonso R (2007) Balance sensory organization in children with profound hearing loss and cochlear implants. Int J Pediatr Otorhinolaryngol 71:629-637. CrossRef Medline

Swillen A, Devriendt K, Legius E, Prinzie P, Vogels A, Ghesquière P, Fryns JP (1999) The behavioural phenotype in velo-cardio-facial syndrome (VCFS): from infancy to adolescence. Genet Couns 10:79-88. Medline

van Amelsvoort T, Denayer A, Boermans J, Swillen A (2016) Psychotic disorder associated with 22q11.2 duplication syndrome. Psychiatry Res 236: 206-207. CrossRef Medline

van Eldik T (2005) Mental health problems of Dutch youth with hearing loss as shown on the Youth Self-Report. Am Ann Deaf 150:11-16. CrossRef Medline

van Eldik T, Treffers PD, Veerman JW, Verhulst FC (2004) Mental health problems of deaf Dutch children as indicated by parents' responses to the Child Behavior Checklist. Am Ann Deaf 148:390-395. CrossRef Medline

van Gent T, Goedhart AW, Hindley PA, Treffers PD (2007) Prevalence and correlates of psychopathology in a sample of deaf adolescents. J Child Psychol Psychiatry 48:950-958. CrossRef Medline

Vitelli F, Viola A, Morishima M, Pramparo T, Baldini A, Lindsay E (2003) Tbx1 is required for inner ear morphogenesis. Hum Mol Genet 12:20412048. CrossRef Medline 
Vostanis P, Hayes M, Du Feu M, Warren J (1997) Detection of behavioural and emotional problems in deaf children and adolescents: comparison of two rating scales. Child Care Health Dev 23:233-246. CrossRef Medline

Walf AA, Frye CA (2007) The use of the elevated plus maze as an assay of anxiety-related behavior in rodents. Nat Protoc 2:322-328. CrossRef Medline

Weisfeld-Adams JD, Edelmann L, Gadi IK, Mehta L (2012) Phenotypic heterogeneity in a family with a small atypical microduplication of chromosome 22q11.2 involving TBX1. Eur J Med Genet 55:732-736. CrossRef Medline

Weiss AH, Phillips JO (2006) Congenital and compensated vestibular dysfunction in childhood: an overlooked entity. J Child Neurol 21:572-579. CrossRef Medline
Wu S, Wu Y, Capecchi MR (2006) Motoneurons and oligodendrocytes are sequentially generated from neural stem cells but do not appear to share common lineage-restricted progenitors in vivo. Development 133:581590. CrossRef Medline

Yagi H, Furutani Y, Hamada H, Sasaki T, Asakawa S, Minoshima S, Ichida F, Joo K, Kimura M, Imamura S, Kamatani N, Momma K, Takao A, Nakazawa M, Shimizu N, Matsuoka R (2003) Role of TBX1 in human del22q11.2 syndrome. Lancet 362:1366-1373. CrossRef Medline

Zweier C, Sticht H, Aydin-Yaylagül I, Campbell CE, Rauch A (2007) Human TBX1 missense mutations cause gain of function resulting in the same phenotype as 22q11.2 deletions. Am J Hum Gen 80:510-517. CrossRef Medline 